\title{
Assessment of Markers of Depression and CD4 Cell \\ Count among Adult HIV-Positive Patients on Anti-Retroviral at a Nigerian University Teaching Hospital
}

\author{
*Amoko A ${ }^{1}$, Ajiboye PO², Olagunju FA ${ }^{1}$, Shittu R.O ${ }^{1}$
}

\begin{abstract}
Objective: Depression is a common mental health problem among people living with HIV/AIDS (PLWHA); because low count of lymphocytes with cluster of differentiation 4 (CD4 cell count) is associated with severe symptoms of HIV infection, there are thoughts that low CD4 cells count can provoke depressive illness. This study was conducted to determine the relationship between CD4 count and depression among adult HIV positive patients attending Family Medicine clinics at University of Ilorin Teaching Hospital (UITH), Ilorin, Nigeria.
\end{abstract}

Method: A hospital based descriptive cross-sectional study was done over a period of 6 months among 350 systematically randomly selected adult HIV-positive patients. PHQ-9 was used to obtain information on depression and the CD4 count was determined using a flow-cytometric method. Data were obtained and analyzed using SPSS-17. Chi-square was used to determine degree of association between the depression and the level of CD 4 count. P-value of $<0.05$ was considered statistically significant.

Results: The prevalence of depression among the respondents was $33.4 \%$. The prevalence of depression was highest among respondents with low CD4 count ( $\leqslant 349$ cells/ul), 37.0\%, and least among those with high CD4 count $(\geqslant 500$ cells/ul), $28.3 \%$. This relationship was however not statistically significant.

Conclusion: The overall prevalence of depression was high among the respondents (33.4\%) suggesting the need for routine depression screening among HIV positive patients. There was no statistically significant association between presence of depression and level of CD4 count ( $\mathrm{p}$-value $=0.302$ ).

Keywords: Depression, CD4count, PLWHA, Family Medicine, UITH.

\author{
*Corresponding Author \\ Amoko A. \\ http://orcid.org/0000-0002-5565-4314 \\ E-mail: amokojt@yahoo.com
}

${ }^{1}$ Department of Family Medicine, University of Ilorin Teaching Hospital, Ilorin.
${ }^{2}$ Department of Behavioural Science, University of Ilorin Teaching Hospital, Ilorin.

Received: June 22, 2019

Accepted: September 4, 2020

Published: December 31, 2020

Research Journal of Health Sciences subscribed to terms and conditions of Open Access publication. Articles are distributed under the terms of Creative Commons Licence (CC BY-NC-ND 4.0). (http://creativecommons.org/licences/by-nc-nd/4.0).

https://dx.doi.org/10.4314/rejhs.v8i4.8 


\title{
Dépression et numération des cellules CD4 chez les patients séropositifs adultes fréquentant les cliniques de médecine familiale d'un hôpital universitaire Nigérien
}

\author{
*Amoko A ${ }^{1}$, Ajiboye PO' ${ }^{2}$, Olagunju FA ${ }^{1}$, Shittu R.O ${ }^{1}$
}

\section{Résumé}

Objectif de l'étude : La dépression est un problème de santé mentale courant chez les PVVIH, et la possibilité d'un faible taux de CD4 comme facteur de risque pour son développement est préoccupante. Cette étude a été menée pour déterminer la relation entre la numération des CD4 et la dépression chez les patients séropositifs adultes fréquentant les cliniques de médecine familiale de l'hôpital universitaire d'Ilorin(UITH), à Ilorin.

Méthode de l'étude : Une étude transversale descriptive en milieu hospitalier a été réalisée sur une période de 6 mois auprès de 350 patients séropositifs adultes systématiquement sélectionnés au hasard. PHQ-9 a été utilisé pour obtenir des informations sur la dépression et le nombre de CD4 a été déterminé en utilisant une méthode de cytométrie en flux. Les données ont été obtenues et analysées à l'aide de SPSS-17. Le chi carré a été utilisé pour déterminer le degré d'association entre la dépression et le taux de CD4. Une valeur $\mathrm{p}<0,05$ était considérée comme statistiquement significative.

Résultats de l'étude : La prévalence de la dépression chez les répondants était de 33,4\%. La prévalence de la dépression était la plus élevée chez les répondants ayant un faible taux de CD4 ( $\leqslant 349$ cellules / ul), 37,0\%, et le moins parmi ceux ayant un taux élevé de CD4 ( $\geqslant 500$ cellules / ul), 28,3\%. Cette relation n'était cependant pas statistiquement significative.

Conclusion : La prévalence globale de la dépression était élevée parmi les répondants (33,4\%), ce qui suggère la nécessité d'un dépistage systématique de la dépression chez les patients séropositifs. Il n'y avait pas d'association statistiquement significative entre la présence de dépression et le taux de CD4 (valeur p =0,302).

Mots-clés : Dépression, décompte des CD4, PVVIH, médecine familiale, UITH

\author{
*Corresponding Author \\ Amoko A. \\ http://orcid.org/0000-0002-5565-4314 \\ E-mail: amokojt@yahoo.com
}

${ }^{1}$ Department of Family Medicine, University of Ilorin Teaching Hospital, Ilorin.
${ }^{2}$ Department of Behavioural Science, University of Ilorin Teaching Hospital, Ilorin.

Research Journal of Health Sciences subscribed to terms and conditions of Open Access publication. Articles are distributed under the terms of Creative Commons Licence (CC BY-NC-ND 4.0). (http://creativecommons.org/licences/by-nc-nd/4.0).

https://dx.doi.org/10.4314/rejhs.v8i4.8 


\section{INTRODUCTION}

A significant number of people living with HIV/AIDS (PLWHA) develop mental health problems of which depression is the most common, with rates 2-3 times higher than the general population (1). Depression is a mental disorder characterized by persistent sadness and loss of interest in previously pleasurable activities, that may be accompanied with inability to carry out daily activities, for at least 2 weeks (2). People with depression may also present with loss of energy; change in appetite; sleeping more or less; reduced concentration; indecisiveness; restlessness; feeling of worthlessness; guilt; hopelessness; or thought of self-arm or suicide (2). According to the findings from global burden of disease, injuries and risk factors study in 2015, depressive illnesses were the third commonest contributors the years lived with disabilities (YLDs) (3).

CD4 cells are white blood cells that play an important role in immune system (4). The level or count gives an indication of the health of the immune status of an individual; those with higher number have stronger immunity while those with lower number have weaker immunity (4). Because individuals with low CD4 cell count, especially when below 200 cells $/ \mathrm{ml}$, are very sick and face more physical and mental challenges, there are thoughts that low CD4 cell count is capable of provoking depressive illness. The other way to consider the relationship between depression and CD4 count is the fact that untreated depression in an HIV positive patient can lead to poor adherence to anti-retroviral care which will lead to poor clinical, immunological and virological status of the patient.

The possibility of low CD4 count level as a risk factor for depression among HIV positive patients has been considered by many authors $(1,5-8)$. A study done by Olisah (5) and his colleagues at Ahmadu Bello University Teaching Hospital, Zaria, Nigeria, showed a prevalence of $14.2 \%$ for depression among HIV-infected participants and patients with CD4 counts of less than 150cells/ul were more likely to be depressed. A study conducted among African-Americans in USA showed a significant association between low CD4 count and presence of major depressive disorders among the respondents(6). One major challenge with studies that show significant association between low CD4 cell count and presence of depression is the possibility to misinterpret some of the symptoms of severe HIV infection due to low CD4 cell counts, such as weight loss, poor sleep, poor appetite, inability to concentrate among others, as symptoms of depression. .

Some studies have also shown no significant relationship between CD4 count and depression among HIV positive patients. A study conducted in 2013 by Eshetu (7) and his colleagues in Ethiopa showed no significant association between depression and CD4 count. Akena (1) in Uganda and Lawler (8) in Botswana also found no significant association between CD4 count level and depression in their various studies.

Our study was meant to determine how common is depression among HIV positive patients, and to know if there is an association between the level of CD4 cell count and presence of depression. This will help in sensitizing healthcare providers on need to be on look out for mental health problems among PLWHA which will enhance the management of this group of patients as a whole. The findings from the study would also help to emphasize the need for incorporation of mental health care into national ART program.

\section{MATERIALAND METHOD}

Study location: The study was conducted at the Family Medicine HIV clinics of University of Ilorin Teaching Hospital (UITH), Ilorin, Nigeria. Ilorin is the capital of Kwara State, a state located in the North-Central geopolitical zone in Nigeria. The state shares boundaries with five other states, namely: Kogi, Ekiti, Osun, Oyo and Niger. The clinics attend to patients from all these states and beyond.

Subjects: The participants were adult patients (18 years and above), attending Family Medicine HIV clinic at UITH, who granted consent to participate in the study. Patients excluded were: patients with other chronic medical illnesses such as diabetes mellitus, systemic hypertension, tuberculosis among others; patients on treatment for depression; patients diagnosed with other major psychiatric disorders such as schizophrenia, bipolar disorder, substance or alcohol abuse among others; and patients that were too sick for clinic consultation.

The total number of respondents recruited was 350. Duration of diagnosis of HIV infection was less than 1 year in $28(8.0 \%)$ respondents, $1-4$ years in 196 (56.0\%) respondents, 5-9 years in $120(34.3 \%)$, and 10 years and above in $6(1.7 \%)$ respondents. 
Design: A hospital based cross-sectional descriptive study was done. Data were collected over a period of 6 months. 350 patients were systematically randomly selected out of the total of 2250 patients that were attending the clinics. The sampling interval was 4.

The sample size was determined using Leslie Kish's formula recommended by Fisher (9) to estimate the minimum sample size in health-related studies, using a prevalence of $29.3 \%$ (10).

$\mathrm{n}=\mathrm{z}^{2} \mathrm{pq} / \mathrm{d}^{2}$

$\mathrm{n}=$ desired sample size when population is greater than 10,000

$\mathrm{z}=$ standard normal deviation, usually set at 1.96 which corresponds to $95 \%$ confidence level.

$\mathrm{P}=$ proportion of the target population estimated to have a particular character. Using a previous study done in Nigeria in 2011, 29.3\% of PLWHA were found to be depressed (10).

Thus, $\mathrm{p}=0.293$

$\mathrm{q}=1-0.293=0.707$

$\mathrm{d}=$ degree of accuracy desired, usually set at 0.05 .

thus, $\mathrm{n}=\frac{(1.96)(1.96)(0.293)(0.707)}{(0.05)(0.05)}=318$

The calculated minimum sample size was 318 but a total of 350 patients were used in the study.

Instruments: Information on prevalence and severity of depression among the respondents was obtained using a structured depression screening tool, Patient Health Questionnaire-9 (PHQ-9). PHQ9 is a structured questionnaire with 9 -items module designed for screening and rating severity of depression in adolescents and adults in primary health care setting (11). It has been validated for use in Nigeria $(12,13)$, having a good concurrent validity with Beck's depression inventory, BDI $(\mathrm{r}=0.84$, $\mathrm{p}<0.001)$ and good one month-test-retest reliability $(\mathrm{r}=0.84, \mathrm{p}<0.001) \quad(13)$. The sensitivity and specificity with 5 as cut-off score for minor depressive disorder is 0.989 and 0.973 respectively, and 0.846 and 0.994 respectively with 10 as cut-off for major depression (13). PHQ-9 is a simple and easy to administer questionnaire for screening of depression. It consists of 9 simple questions, making the tool fast and easy. It has been recommended as depression screening tool for primary care physicians. There is however need to subject positive patients to one of the recommended diagnostic tools to confirm the presence of depression. Each of the nine questions is rated 0 to 3 . Not at all $=0$; several days $=1$; more than half the days $=2$; and nearly every day $=3$. The interpretation of the total scores is as follows: $0-4=$ no depression and 5-27= depression.

The questionnaires were administered by the researchers. A systematic randomized sampling technique was used in recruiting patients for the study. The Family Medicine HIV clinic at UITH is run once in a week, and the average number of patients seen per clinic day was 60 patients. The number of patients needed to be interviewed per clinic day to cover 350 respondents in 6month was 15 patients $[350 /(6 \times 4)]$. The sampling interval is, thus, $60 / 15=4$. On every clinic day each folder was assigned a number from 01 to 60 . The first subject was selected by balloting and thereafter every 4 th subject that met the inclusion criteria was chosen until the required sample size for the clinic day was met.

The respondents' CD4 counts were determined using an automated flow cytometric machine (Cytoflow SL3, manufactured in Germany, 2007). CD4 cell count was used as marker of the extent/severity of HIV infection in this study because it is a more reliable than clinical staging. Viral load is a better marker of the extent/severity of HIV infection but it could not be used because of the cost and the fact that the equipment for its measurement was not available in the centre where this study was conducted.

Data management and analysis: The duration of HIV disease from diagnosis was categorized into four groups: less than 1year, 1-4 years, 5-9 years and $10 y e a r s$ and above. The level of CD 4 cell counts were grouped into 3groups: 349cells/ul and below (low); 350-499 cells/ul (moderate); and 500 cells and above (high). For those who are depressed, the severity of the depression was grouped into four using PHQ-9 scores: $5-9=$ mild depression; $10-14=$ moderate depression; $15-19=$ moderately severe depression; and $20-27$ = severely (extremely) severe depression. All data were analyzed using SPSS-17. The level of significance of the association between the CD4 cell count groups and depression and depression severity was determined using Chi-square. Confidence interval of $95 \%$ was used and a p-value of less than 0.05 was considered statistically significant.

Ethical issues: Informed consents were obtained from the participants and patient confidentiality was maintained. All ethical principles guiding a research of this nature were strictly adhered to, and ethical 
approval was obtained from Ethical Review Committee of University of Ilorin Teaching Hospital. All financial obligations as regard this study were borne by the researchers, and there was no involvement of any party that could result to conflict of interest.

\section{RESULTS}

Table 1 shows the socio-demographic characteristics of the respondents. A total of 350 respondents were analyzed, 109 (31.1\%) males and $241(68.9 \%)$ females, giving a male to female ratio of 1:2.2. Respondents ages range from 21 to 80 years with mean age of 42.12 years ( $\mathrm{SD} \pm 1.03)$. Most of the respondents were in their early and mid adulthood with age group 30-39 years having the highest number of participants [126(36.0\%)]. Majority of the respondents were currently married $(67.7 \%)$ and
$58.0 \%$ of the respondents had more than primary level of education. A large number of the respondents were traders (44.6\%). Five (1.4\%) of the participants were Non-Nigerians; and majority of the respondents were from Yoruba ethnic group. More participants $(53.7 \%)$ practiced Islam, and only $2.9 \%$ of the respondents were unemployed.

Table 2 shows the distribution of the respondents CD4 counts into the three groups. Majority of the respondents had CD4 count of 349 cells/ul and below (41.7\%), followed by those with CD4 count of 500 cells/ul and above (36.3\%) and then those with CD4 counts between 350 and 499 cells/ul (22.0\%).

Table 3 shows the prevalence of depression among the respondents. Among the 350 participants, 117 respondents were depressed, giving a depression prevalence of $33.4 \%$.

Table 1: Socio-demographic characteristics of the respondents

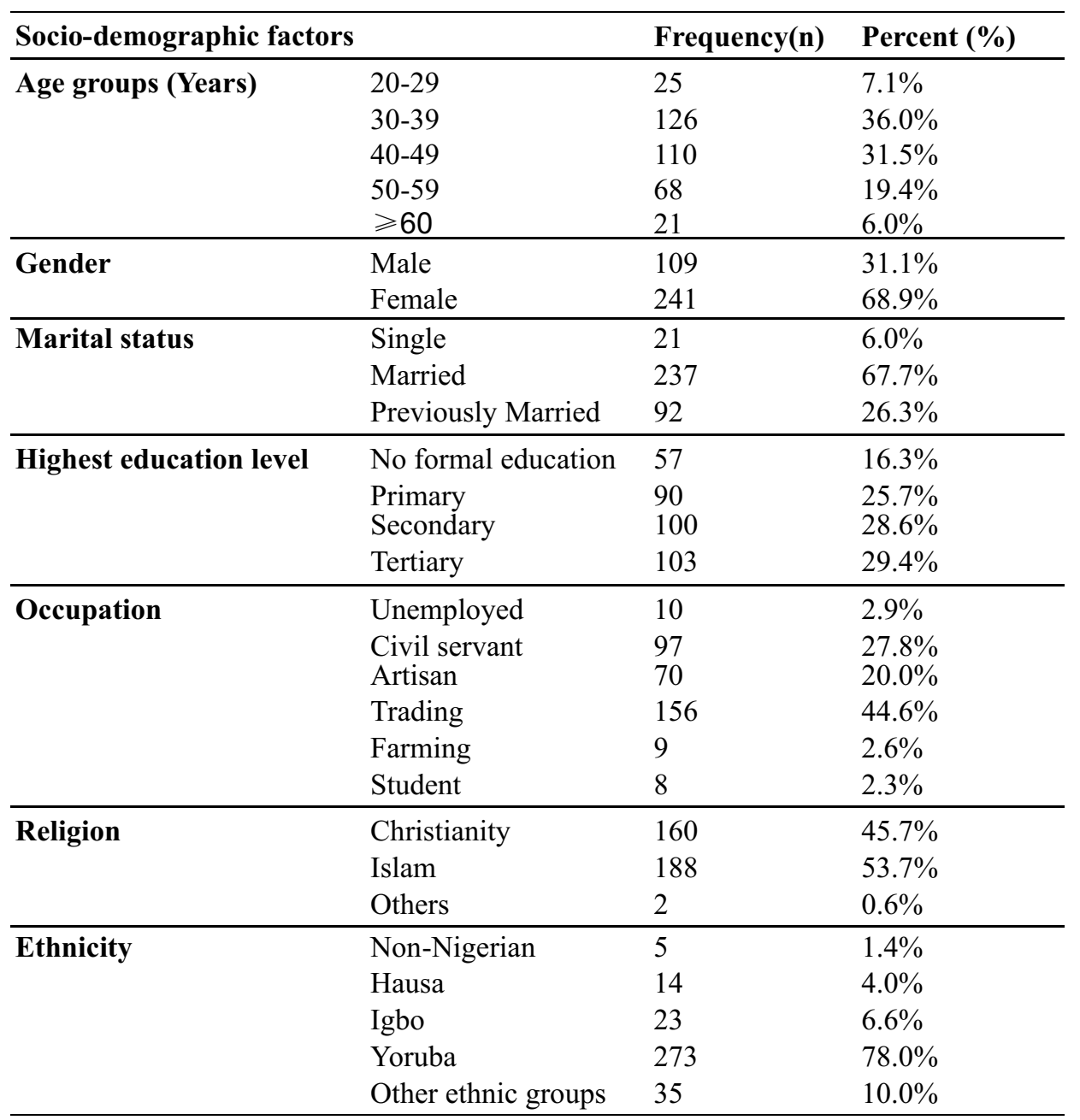


Table 2: Current CD4 Count Level

\begin{tabular}{lll}
\hline CD4 Count (cells/ul) & Frequency & Percentage (\%) \\
\hline$\leqslant 349$ (Low) & 146 & 41.7 \\
$350-499$ (Moderate) & 77 & 22.0 \\
$\geqslant 50 \varphi$ High) & 127 & 36.3 \\
Total & 350 & 100 \\
\hline
\end{tabular}

Table 3: Prevalence of Depression among the Respondents Using PHQ-9 Scores

\begin{tabular}{lll}
\hline PHQ-9 Score & Frequency & Percentage \\
\hline 0-4 (Not Depressed) & 233 & $66.6 \%$ \\
5-27 (Depressed) & 117 & $33.4 \%$ \\
Total & 350 & $100 \%$ \\
\hline
\end{tabular}

Table 4: Association between the CD4 Count Level and Depression among the Respondents

\begin{tabular}{|c|c|c|c|c|c|c|}
\hline & $\begin{array}{l}\text { Not Depressed } \\
\mathrm{N}_{1}=233, \mathrm{X}_{1}(\%)\end{array}$ & $\begin{array}{l}\text { Depressed } \\
\mathrm{N}_{2}=117, \mathrm{X}_{2}(\%)\end{array}$ & $\begin{array}{l}\text { Total } \\
\mathrm{N}=350, \mathrm{X}(\%)\end{array}$ & $\mathbf{X}^{2}$ & df & p-value \\
\hline$\leqslant 349$ cells $/$ ul & $92(63.0)$ & $54(37.0)$ & $146(100)$ & & & \\
\hline $\begin{array}{l}350-499 \text { cells } / \text { ul } \\
\geqslant 500 \text { cells } / \text { ul }\end{array}$ & $\begin{array}{l}50(64.9) \\
91(71.7)\end{array}$ & $\begin{array}{l}27(35.1) \\
36(28.3)\end{array}$ & $\begin{array}{l}77(100) \\
127(100)\end{array}$ & 2.397 & 2 & 0.302 \\
\hline
\end{tabular}

$\mathrm{N}=$ Total number of respondents, $\mathrm{N}_{1}=$ Total number of respondents not depressed (PHQ-9=0-4), $\mathrm{N}_{2}=$ Total number of depressed respondents (PHQ-9=5-27), $X_{1}=$ number of respondents not depressed affected by the variable, $X_{2}=$ numbers of depressed respondents affected by the variable, $X=$ Total number of respondents affected by the variable, $\%=$ Percentage of respondents in each variable group. $\mathrm{X}^{2}=$ Chi square value, $\mathrm{df}=$ degree of freedom

Table 4 shows the relationship between CD4 count level and depression among the respondents. Respondents with CD4 count of 349 cells/ul and below had the highest prevalence of depression (37.0\%) while those with CD4 count of 500cells/ul and above had the least prevalence of depression $(28.3 \%)$. The relationship was however not statistically significant $(\mathrm{p}$-value $=0.302)$.

\section{DISCUSSION}

The prevalence of clinical depression among the respondents was $33.4 \%$ using the Patient Health Questionnaire-9 (PHQ-9) scores. Similar high prevalence, 29.3\%, was obtained by Aromeh (10) and colleagues in their study in nineteen AIDS-Relief centres in Nigeria, in 2010, using Depression, Anxiety and Stress Scale-21 (DASS-21). This figure is also comparable to $38.5 \%$ obtained by Lawler (8) and others in Botswana, 2011, using Beck's Depression Inventory-Fast Screening for medical patients. It is however higher than $8.1 \%$ obtained by Kinyanda (14) and colleagues in Uganda, 2010, using Mini International Neuropsychiatric interview, and less than $44.6 \%$ (depression and borderline depression) obtained by Ndu (15) in South Eastern
Nigeria, 2010, using Hospital Anxiety and Depression Scale (HAD).

The wide variation in prevalence of depression in these studies may be due to differences in sensitivity of the screening tools as well as in the composition of the study populations. It may also be due to the difficulty in assessing depression (especially the somatic symptoms) in somatically ill patients or the geographical differences.

The relationship between the CD4 count level and depression among the respondents was such that respondents with low CD4 count $(\leqslant 349$ cells/ul) had the highest prevalence of depression $(37.0 \%)$ while those with high CD4 count ( $\geqslant 500$ cells/ul) had the lowest prevalence of depression (28.3\%).This relationship was however not statistically significant $(p=0.302)$. Akena (1) and his colleagues in Uganda had a similar finding in their study in which they found no statistically significant association between low CD4 count and presence of depression. Lawler (8) in Botswana also found no statistically significant association between low CD4 count and depression. A study conducted in 2013 by Eshetu (7) and his colleagues in Ethiopa showed no significant association between depression and CD4 count. 
However, some studies have shown a statistically significant relationship between low CD4 count and higher prevalence of depression among HIV positive patients. A study done by Olisah (5) and his colleagues at Ahmadu Bello University Teaching Hospital, Zaria, Nigeria, showed a prevalence of $14.2 \%$ for depression among HIVinfected participants and patients with CD4 counts of less than 150 cells/ul were more likely to be depressed. A study conducted among AfricanAmericans in USA showed a significant association between low CD4 count and presence of major depressive disorders among the respondents (6).

In our study we initially thought that because low CD4 count is usually associated with severe symptoms of HIV infection such as severe weight lost, opportunistic infections and cancers, low CD4 count should provoke depressive illness in the patients. This study, even though it shows that depression was more common in patients with low CD4 count, did not show a statistically significant association (p-value-0.302). Absence of significant association between depression and CD4 count in our study may be due to some reasons. One of the reasons may be due to the sample size used in our study, a larger sample size might have produced a statistically significant association. Another reason why we may not have found statistically significant relationship between depression and low CD4 cell count in our study may be because our study was a cross-sectional study and only a single CD4 count result was used for each respondent. Monitoring depression prevalence and CD4 counts of these patients over a reasonable period of time (longitudinal study) may have shown a significant relationship as seen by Olley (16) and his colleagues in their study in which increase in depression prevalence was found to be significantly associated with decline in CD4 count after following up the patients for at least 6 months.

In conclusion, the study found a high prevalence of depression (33.4\%) among adult HIV positive patients. There is therefore need to routinely screen all adult HIV positive patients for depression when they present to hospital. The study also found higher prevalence of depression among patients with low CD4 cell count ( $\leqslant 349$ cells/ul); this relationship was however not statistically significant. We are of the opinion that a larger sample size may produce a statistically significant relationship. We therefore recommend larger sample size for subsequent similar studies. A further study is also recommended to explore other factors relating to depression in HIV patients.

\section{CONFLICT OF INTEREST}

All financial obligations as regard this study were borne by the researchers, and there was no involvement of any party that could result to conflict of interest.

\section{ACKNOWLEDGEMENT}

We want to acknowledge the resident doctors of the department of Family Medicine, UITH, the Consultants in charge and all staff of the HIV Clinics of UITH, particularly the nurses and the social welfare staff, for the support they gave us when we conducted this study.

\section{REFERENCES}

1. Akena DH, Musisi S, Kinyanda E. A comparison of the clinical features of depression in HIV-positive and HIV-negative patients in Uganda. Afr $\mathrm{J}$ Psychiatry 2010;13:43-51.

2. Priyanmuanda R, Ranjan R, Shukla P, Chaudhug S. Depression in HIV positive male and female patients. RINPASS Journal 2011;3(1):78-84.

3. Global Burden of Disease 2015 Diseases and Injury Incidence and Prevalence Collaborators. Global, regional, and national incidence, prevalence, and years lived with disabilities for 210 diseases and injuries, 1990-2015: a systematic analysis for Global Burden of Disease study. Lancet 2016; 388 (10053):1546-1602.

4. Greater Hughson. CD4 cell count. Aidsmap May 2017. Available at: https://www.aidsmap.com/abouthiv/cd4-cell-counts\#: :text=CD4\%20cells\%20are\% 20white\%20blood, \%2Dlymphocytes\%2C\%20or\%2 0helper\%20cells. Accessed on 30/08/2020.

5. Olisah VO, Adekeye O, Shelkh TL. Depression and CD4 cell count among patients with HIV in a Nigerian University Teaching Hospital. Int $\mathrm{J}$ Psychiatry Med 2015; 48(4): 253-61.

6. Amanor-Boadu S, Hipolito MMS, Rai N, McLean CK, Flanagan K, Hamilton FT et al. Poor CD4 count a predictor of untreated depression in Human Immunodeficiency Virus-positive African American. World J Psychiatry 2016;6(1):128-135

7. Eshetu DA, Woldeyohannes SM, Kebede MA, Techane GN, Gilachew KD, Tegegne MT. Prevalence of depression and associated factors 
among HIV/AIDS patients attending ART clinic at Debrebirhan referral hospital, Amhara Region, Ethiopa. Clinical psychiatry 2014. Available at: https://clinical-psychiatry.imedpub.com/prevalenceof-depression-andassociated-factors-amonghivaids-patients-attending-art-clinicat-debrebirhanreferral-hospitalnorth-showa-amhara-region ethiopia.php?aid=7463 Accessed 02/09/2020

8. Lawler K, Mosepele M, Seloilwe E et al. Depression among HIV-positive individuals in Botswana: a behavioural surveillance. AIDS Behav 2011;15:2048.

9. Fisher AA, Laing JE, Stoeckel JE, Townsend JW. Estimation of minimum sample size in Health Related Studies. Handbook for Family Planning Operation Research Design. 2nd ed. New York; Population Council:1998. Pp 43-45.

10. Aromeh AV, Okeke M,Akpenna D, Enwerem F, Okoye R, Obiefune $\mathrm{M}$ et al. Depressive symptoms in HIV positive patients in AIDSRelief ART sites in Nigeria. Proceedings of $6^{\text {th }}$ International AIDS Society Conference on HIV Pathogenesis, Treatment and Prevention; 2011 July 17-21; Rome, Italy.

11. Kroenke K, Spitzer RL, Williams JBW. The PHQ-9: Validity of a brief depression measure. J Gen Intern Med 2001;16(9):606-13.

12. Ogunsemi O, Oluwole F, Abasiubong F, Erinfolami
A, Amoran O, Ariba A et al. Detection of mental disorders with Patient Health Questionnaires in primary care settings in Nigeria. Mental Illness, 2010 Oct 2. [Online]. Available from: URL: http://pagepress.org/journal/index.php/m:/article/vi ew/m:2010.e10. [Accessed on 14th November, 2011].

13. Adewuya AO, Ola BA, Afolabi OO. Validity of Patient Health Questionnaire- 9 (PHQ-9) as screening tool for depression amongst Nigerian university students. Journal of Affective Disorders 2006;96(1):89-93.

14. Kinyanda E, Hoskins S, Nakku J, Nawaz J, Patel V. Prevalence and risk factors of major depressive disorder in HIV/AIDS as seen in semi-urban Entebbe district, Uganda.

15. Ndu AC, Arinze-Onyia SA, Aguwa EN, Obi IE. Prevalence of depression and roles of support groups in its management: A study of adult HIV/AIDS patients attending HIV/AIDS clinic in a tertiary health facility in South-Eastern Nigeria. J Public Health Epidemiol 2011:3(4):182-6.

16. Olley B.O, Seedat S, Neil DG, Stein DJ. Predictors of major depression in recently diagnosed patients with HIV/AIDS in South Africa. AIDS Patient Care STDs 2004; 18(8):481-7. 